\title{
The Rebellious, Untamed Mare: Morrison's Heroine Sula
}

\author{
Afaf Ahmed Hasan Al-Saidi \\ Department of English, College of Languages and Translation, King Khalid University, Abha, K.S.A; \\ College of Education, Aden University, Republic of Yemen \\ Shunayfaa Muhammed Alqarni \\ Department of English, College of Languages and Translation, King Khalid University, Abha, K.S.A
}

\begin{abstract}
In her novel Sula, Toni Morrison creates one of the few black heroines to deliberately enhance the role of a pariah. This paper tries to unfold the rebellious attitude against the norms of the black community that mainly revolves around male's centered society. Sula considers herself a free spirit who challenges and goes beyond all the boundaries; she dares to confront every aspect of that society. Her personality is remarkably evolved since childhood, whether with her relation with her grandmother; her mother or her friend Nel Wright as well as with her lovers. Being raised in household of strong women shapes the person she becomes; fearless, rebellious and daring.
\end{abstract}

Index Terms-Morrison, Sula, rebellious, the loss of innocence, friendship, norms and customs, black community

\section{INTRODUCTION}

Since the 1970s and 1980s, black women writers have come into their own and their voice now resounds throughout the world. But it has been a long struggle for recognition. Black women's stories celebrate the role of women in a communal survival. They show how women survived "to become mistresses of their own private and increasingly, their public world" (Busia, 1988, p.29).

During the late $19^{\text {th }}$ century, many African-American women writers of fiction changed their writing from antislavery to sexism and racism. "But in their fiction, the theme of sexism was not prominent" (Young, 1993, p.48).

From the end of the $19^{\text {th }}$ century until World War I, the United States progressed rapidly, becoming an industrial nation strongly competing with European nations. In spite of the migration of black Americans towards the North and the better opportunities and good payment, the social status of African-American women remained unchanged.

In the early 1940s, Richard Wright and other male writers became the dominant figures of African- American writing.

In the 1960s, the American nation was in turmoil. There was a belief among African-Americans that black men and women were unified in their fight for freedom. But gradually, black women began to experience "a sense of betrayal with respect to their match-revolutionary brothers" (Russell, 1991, p.86).

From the antislavery and women rights movement of the nineteenth century, continuing through the black women rights movements of the 1960s and 1970s, up till today's contemporary black feminism, black women writers asked to have their voices back, (africandiasporaphd.com) since the two centuries of struggle had silenced them. Their voices now resound throughout the world asking for recognition.

Black women writers, through every type of literature, fiction, nonfiction, poetry, essays, autobiographies and others, gave voice to the buried stories of the black women, which expressed their lives, and reflected all the difficulties and sufferings, black women faced in existing in a society full of violence. Mary Helen Washington in her book Midnight Birds: Stories of Contemporary Black Women Writers (1990, p.17) writes:

Black women are searching for a specific language, specific symbols and specific images with which to record their lives and even, though they can claim a rightful place in Afro American tradition and the feminist tradition of women writers, it is also clear that for purposes of liberation, black women writers will first inscribe their name, their own space. (baadalsg.inflibnet.ac.in)

The 1980s and 1990s were important periods in which a growing number of magnificent women writers and critics emerged such as Toni Morrison, Alice Walker, and Maya Angelou. They represented the latest flowering of this tradition of black female writing. Those writers have changed the face of black American literature and their appearance marked a further significant development. Their writing showed unique characteristics which emerged from their unique position of being black female and artist. Their voices have been heard widely in published works and academia. They showed how women have survived in order to get recognition. Barbara Christian (1980, p.240), demonstrated how and why the emergence of African- American novelists is important. Morrison and other women writers, as Christian stated, criticized the white and black communities for their devaluation the African- American women. With their 
criticism, they gave a voice back to the black women and the problems they faced:

Black communities are clearly one of the many audiences Morrison and Walker addressed their first novels, for both works critique those com-munities and insist that they have deeply internalized racist stereotypes that radically affect their definition of woman and man (othes.univie.ac.at).

In her Nobel Lecture in 1993, delivered in Stockholm, Morrison demonstrated how through her novels, she could reflect the world of the black people, and how language could shape the human reality. Through her own use of the spoken and written words, she has created new spaces for readers, to bring their imagination and their intellect to the complex, cultural, political, social and historical issues of her time (docplayer.net). She places high value on the freedom of black women, and deals in her writing with the community's fright of change and for the most the significance of womanly relationship. In her essay "Rootedness: The Ancestors as Foundation," (1984) she writes:

If anything I do, in the way of writing a novel or whatever I write, isn't about the village or the community or about you, then it isn't about anything. I am not interested in indulging myself in some private exercise of any imagination ... which is to say yes, the work must be political. (p.339)

\section{THEMATIC CONCERN}

In her novel Sula, as (McKay, 1988, p.5) declares, Morrison creates one of the few black women heroines "to deliberately embrace the role of a pariah" (repositorio.ual.es).

Morrison's Sula spans the years 1921 to 1965. In Sula we enter the world of The Bottom, the black section of the town up in the hills of Medallion, Ohio. The Bottom is a land promised to a slave by his master as a reward of freedom, but the antithesis of its meaning. The master, realizing that the bottom land was fertile, and the top land was unyielding, tricked the slave into acceptance of the hilly land. When the slave blinked at this, the master stated "the land is 'high' up from us ... but when God looks down, it's the bottom. That's why we call it so. It's the bottom of heaven best land there is" (Sula, p. 5).

Sula in form and content is about "gabs, lacks, missing subjects, and ambiguous psychic space, all of which must be 'filled' and interpreted by the reader" (Grant, 1988, p.94). Morrison has commented in her narrative technique in Sula as Tate asserts (1989, p.125): "My writing expects, demands participatory reading. ... It's not just about telling the story; it's about involving the reader. The reader supplies the emotions. The reader supplies even some of the color, some of the sound. My language has to have holes and spaces and the reader can come into it."

Morrison's Sula is about the lack of freedom of black women and "the community's fear of change and experimentation and above all the importance of female friendship" (Wisker, 2000, p.61). The basic theme of the novel concerns the friendship of two girls growing into womanhood; Sula Peace and Nel Wright. In the framing of their story in the community of the Bottom, "we have the setting that moulds them into who they are... the community is the context within which these women search for self-definition" (Russell, 1991, p.96). Barbara Christian sees it thus: "the story is not only about Nel Wright and Sula Peace; it is most emphatically about the culture that spawns them" (Black Women Novelists, 1980, p.153). And this culture, this place and the people who inhabit it, give the reader some of "the most intriguing and complex characters to unfold in black American literature" (Russell, p.96). Toni Morrison explained to Robert Stepto (1979, p.214) in an interview:

When I wrote Sula, I was interested in making the town, the community, the neighborhood, as a strong character as I could ... because the most extra-ordinary thing about any group, and particularly our group, is the fantastic variety of people and things and behaviour and so on (shodhganga.inflibnet.ac.in).

Sandi Russell (1991) comments that in Sula "the forces of Nature are essential" and inextricably linked to life, death and time, Images of water, fire, earth and wind pervade the novel and are signals or omens of events as well as relating to the personalities of characters" (p.97). The image of nature's forces, semiotically, indicate the forces that interweave the complexities of the novel's major characters and are responsible for who they are.

Sula's environmental circumstances are responsible for shaping her independent rebellious character. Sula comes from a line of non-conventional woman, a household where "women simply loved maleness for its own sake" (Sula, p.41). Her grandmother, Eva Peace, is forced to take desperate measures to save her children from starvation after her husband abandons them: she purposely loses a leg on the railroad track in order to collect the insurance money.

Sula, who is neglected as a child, grows up in a crowded household governed by her powerful grandmother, with a gentle mother who is devoted to the practice and pleasure of her desire. The scene in Sula's imagination when she is alone in the attic indicates her wild sensuous and untamed personality:

Sula ... wedged into a household of throbbing disorder constantly away with things, people, voices and the slamming of doors, spent hours in the attic behind a roll of linoleum galloping through her own mind on a gray-and- white horse testing sugar and smelling roses in full view of someone who shared both the taste and speed. (Sula. pp. $51-52)$

Sula finds in her friend Nel Wright the opposite of her own nature. As children they share each other's dreams of 
freedom and excitement, but there is a special knowledge they both share; because "they discovered years before that they were neither white nor male, and that all the freedom and triumph were forbidden to them" (Ibid. p.52).

As Sula grows into womanhood, she fights against the prescribed role for black women of the community to 'make someone else.' And because there is no other definition in her life, "she's like water and assumes the shape of whatever holds her" (Morison, Talk at Conference, 1985).

The water is a symbol of the supreme sky, and stands for purity, but in this case, it is compared to the shapeless, aimless Sula. Toni Morrison see this as a metaphor for the talented black woman "whose gifts are not taken seriously" (1985).

Living with her mother Hannah in the house of her grandmother Eva, Sula originally draws her world view from both women. However, her incapability to find meaning in the prearranged domestic roles of the women of the Bottom, coupled with her desire to be "distinctly different" (Sula, p.118), indicates how Sula is spiritually and physically alienated. "She had no center, no speck around which to grow" (Ibid. p.103):

Her weirdness, her inexperience, her yearning for the other half of her equality was the consequence of an idle imagination. "Had she paints, or clay, or knew the discipline of dance... had she anything to engage her tremendous curiosity and her gift for metaphor, she might have exchanged the restlessness and preoccupation with whim for and activity that provided her with all she yearned for. And like any artist with no art form, she became dangerous". (Ibid. p.121)

In most of her novels, Morrison repeatedly "translates the body itself into political speech" (Rigney, 1991, p.25). Eva's act of self-mutilation in Sula reflects the determination to stay alive, but it is also a statement representing poverty and circumstances of life for black women. As Eva endures the mutilation of her leg, so also Sula cuts off the top of her won finger to protect herself and Nel form offensive white boys and also successfully to issue a warning. Using her body, Sula confronts these white boys: "If I can do that to myself, what you suppose I'll do to you?" (Sula, p.47). Even the white boys understand how dangerous she is. Self-inflicted marks constitute the most original development in Morrison's employment of this form of projection:

As opposed to congenital or acquired marks perceived as sings of distinction, the self-inflicted mark transforms the bodily text into a form of heroic dialogue between characters and adversity, and the signifier into a fully realized signification. The act of marking is appropriated by the oppressed individual in order to retaliate against the oppressor (Harding and Martin, 1994, p. 23).

Self-disfigurement is a metaphor which represents the individual's direct hostility with oppressive social forces crucial in white domination. Marks become an imaginative representation of racial difference. "Because self-mutilation functions as a literary figure, self-mutilation is liberational and contrasts sharply with all the other forms of violence done to the self-portrayed in Morrison writing" (Willis, 1982, p.39). The cruel dilemma of self-mutilation already experienced by Eva and Sula becomes and explicit gesture of rebellion.

Sula's birthmark sits in her eyelids as a sing of her "exceptional destiny" in the Bottom community. Her birthmark is a "constantly renewed symbolism expressing Sula's personality as a response to other" (Harding and Martin, 1994, p.22).

Sula, like the serpent her birthmark sometimes represents, "challenges the arrested innocence guarded by Nel's mother" (Otten, 1989, p.32). She fulfills Nel's will to be free of her mother Helene's smothering goodness, a desire Nel first shows on the trip to New Orleans. "Nel felt both pleased and ashamed" (Ibid. p.32) to witness the 'stricken' look of the two black soldiers on the train when they see Helen's 'dazzling smile' at the white racist conductor. Their 'bubbling hatred' manifests "something of her [Nel's] own unconscious desire" (Ibid. p.32).

When she returns to Medallion, she stares at her mirror and, in open rebellion, declares her transformation into another stage of her life: discovering 'me-ness' and self-love. Nel's spoken words of assertion of selfhood are indications of pride and certainty of identity, a creative act that makes Nel self-reliant. She imposes herself against familial obligation. For Nel, the mirror reflects not a concept called Nel, but something 'other':

There was her face, plain brown eyes, three braids and the nose her mother hated. She looked for a long time and suddenly a shiver ran through her. "I'm me," she whispered. "Me".

Nel didn't know what she meant, but on the other hand she knew exactly what she meant. I'm not Nel. I'm me." (Sula, pp. 28-29).

The narrator concludes, "The trip, perhaps, or her new found Meness, gave her strength to cultivate a friend in spite of her mother" (Ibid. p.29). Helen drives "her daughter's imagination underground" (Ibid. p.16). Sula animates Nel's will to power. Sula becomes the "Other" and fulfills the role attributed to the "double" as stated by Karl Miller: "one self does what the other self can't. One self is meek [i.e. Nel] while the others is fierce" (p. 45). Sula articulates what Miller calls "the rule of contraries, which is another name for the double, with its constant inversions and reversal" (p. 45). Sula and Nel counter-balance each other, "They exist in tenuous balance as they grow to womanhood - Nil leans on Sula, and Sula seeks reassurance in Nel's ordered world" (Otten, 1989, p.34). They together share the loss of innocence "in a series of expressions ... when they are both twelve, the age of accountability" (Ibid. p. 4). By this time $\mathrm{Nel}$ is no longer interested in straightening her hair with hateful hot comb, and both she and Sula strike a new theme - 
"me." They secretly rejoice when the young black men praise them and call them "pig meat" and "smooth vanilla crotches" (Sula, p.50).

At this age of heightened sensitivity, Sula suffers a severe shock when she overhears her mother says "I love Sula but I don't like her" (Ibid. p.57). Twelve years old Sula escapes with Nel into the bright summary day to the river where they fling themselves "into the four-cornered shade to taste their lip sweet and contemplate the wildness that had come upon them suddenly" (Ibid. p.58).

On the edge of sexual awakening, while lying on the grass, "their foreheads almost touching, their bodies stretched away from each other at a 180- degree angle. ... Underneath their dress flesh tightened and shivered in the high coolness, their small breasts just now beginning to create some pleasant discomfort when they were lying on their stomachs"(Ibid. p.58).

The scene indicates the burial of their childhood "and foreshadows a demonic if unwitting will to power" (Otten, 1989, p.35). They each begin to undress a twig" by stripping it down to a smooth creamy innocence" (Sula, p.58), and begin to dig the ground until Nel makes "a small neat hole that grew deeper and wider with the least manipulation of her twig" (Ibid. p.58). Sula imitates her until they make the two holes "one and the same" (Ibid. p.58). When Nel's twig breaks, she throws the pieces into the hole they have made:

Sula threw hers in too. Nel saw a bottle cap and tossed it in as well. Each then looked around for more debris to throw into the hole: paper, bits of grass, butts of cigarettes, until all of the small defiling things they could find were collected there. Carefully they replaced the soil and covered the entire grave with uprooted grass. Neither one had spoken a word (Sula,. pp.58- 59).

This richly sexual moment signals their imminent passage into experience, their joint fall from childlike innocence. "It occurs when Sula tempts the recently arrived boy Chicken Little to climb a tree by the river" (Otten, 1989, p.35). The dynamics of Toni Morrison's body language is visualized through the attitude of the two girls towards males.

Morrison's body language is dramatized through the actions of the rebellious, violent Sula. Sula's experiences in life are somehow rooted in her capacity to begin violence. She accidentally, drowns Chicken Little who appears at the moment she and Nel begin to discover their own sexuality while lying together on the grass. She begins playfully swinging Chicken Little around and around so vigorously that he slips from her hands into the river. They watch Chicken Little drown. "Guilty, they stare at darkened water, no longer able to claim innocence" (Otten, 1989, p.35). Ironically, Nel tells the nearly hysterical Sula, "You didn't mean to. It ain't your fault" (Sula, pp.62-63), trying to preserve an innocence she has herself lost. Although Nel thinks she has done nothing, she feels "convicted and hanged" (Sula, p.65). Nel herself does not recognize her guilt for "it is she and not Sula who taunts Chicken" (Otten, 1989, p.36).

The loss of their innocence gradually leads to their separation; their bodies emphasize the distance between them at Chicken Little's funeral: they did not touch hands or look at each other during the funeral. "There was a space, separateness between them" (Sula, p.64). They sit passively during the ceremony with unfolded hands, "like pairs of raven's wings" (Ibid. p.65), suggesting a sense of total helplessness. They leave Chicken's funeral, walking home with "their fingers ... laced in as gentle a clasp as that of any two young girlfriends trotting up the road on a summer day wondering what happened to butterflies in the winter" (Ibid. p.66). The scene effectively evokes the sense of lost innocence.

Among the significant moments of Sula's life is her recognition of the "closed place in the water" where he disappears, the "something newly missing" (Sula, p.61). By providing Sula and Nel with the secret of Chicken Little's accidental death, "and among the significant moments of Sula's life is her recognition specifically by having Nel provide the strength and support Sula needed at the moment" (Samuels and Hudson-Weems, 1990, p.45), Morrison further unites them in a manner that will "bound them for eternity" (Ibid. p.45).

Although Sula who slips Chicken Little's hands, but the involvement, as her grandmother Eva later points out, is clearly theirs together. It is Nel who suggests 'the cover-up' when she tells Sula, "Let's go. We can't bring him back" (Sula, p.146). There is a sadistic pleasure which Nel can only confess years later: "She didn't feel bad about the Chicken Little drowning. How come it felt so good to see him fall?" (Ibid. p.170). When Eva, years later questions Nel about the accident, Nel tries, consciously, to protect her innocence: she avoids not only the question but the more indirect suggestion of guilt; she denies herself:

Tell me how you killed that little boy?

What? What little boy?

The one you threw in the water....

I didn't throw no little boy in the river. That was Sula.

You. Sula. What's the difference? You was there.

You watched, didn't you? ... Never was no difference

between you. (Sula, pp.168-169)

According to Morrison, although Nel lacks Sula's imagination, "they are very much alike. They complement each other. They support each other" (Parker, 1979 p.253). Sula represents the dark unconscious, "the 'evil' underside of the imagination" (Otten, 1989, p.34) - what Morrison has labeled "a classic type of evil force, yet not freakish or repulsive or unattractive" (Stepto, 1979, p.215). She lives her days exploring her emotions and thoughts; she feels no obligation to please anybody unless their pleasure pleases her. "As willing to feel pain as to give pain, to feel pleasure, hers was an 
experimental life" (Sula, p.118), which indicates that Sula is a free spirit not bound by external mores and values. She expresses her wild, untamed nature when she declares to Nel:

I got my mind. And what goes on in it.

Which is to say, I got me.

Lonely, ain't it?

Yes. But my lonely is mine (Sula, p.143)

Sula becomes a pariah "precisely because she rejects those values that aim at uniformity and stifle the self" (Banyiwa -Horne, 1985, p.31). Her inclination to discard them makes her "evil" to those in the communal who never direct their own freedom of the will. Sula is "evil"" because she, unlike Nel, "does not live totally by the law nor surrender completely to it without questioning anything: sometime she is perfectly willing to think the unthinkable" (Stepto, 1979, pp.216-217). She is responsible to no one but herself for the track of her life. Her strength to adopt existential obligation for self is indicated by her assertive declaration: "I got my mind" (Sula, p.143), a creative declaration of self-will which to do what one wishes.

The relationship between Sula and Nel is severed only when Nel marries Jude five years later, an unexceptional young man who think of Nel as "the hem, the tuck and fold that hide his raveling edges"(Ibid. p.83). Sula's inventive wildness cannot overcome social pressure or influence of Nel's parents "who had succeeded in rubbing down to a dull glow any sparkle or splutter she had" (Ibid. p.83). Nel becomes prey to convention while Sula escapes it. The wedding of Nel ends the first phase of their relationship. The scene is significant when Nel's final action is to look past her husband toward Sula; despite their separation and different paths, Nel signifies their closeness and intimacy:

A slim figure in blue, gliding, with just a hint of a strut, down the path towards the

road. ... Even from the rear Nel could tell that it was Sula and that she was smiling;

that something deep down in that litheness was amused (Sula, p.85).

When Sula returns, ten years later, her rebelliousness "full blown, a major source of the town's suspicions" (Sula, p.79) springs from the fact that she is almost thirty, still unmarried. The verbal exchanges Sula has with her grandmother, signifies the impact the Peace women have on their progeny. When Eva asks: "When you gone to get married? You need to have babies. It'll settle you," Sula flares up "I don't want to make somebody else. I want to make myself," but Eva insists this is selfish, "Ain't woman got no business floating' around without no man" (Ibid, p.92). Sula's existential pronouncement "I want to make myself" is the adult voice, the voice of Sula-as-a-woman that we hear: As McDowell (1988) declares, "Self-definition is a dangerous activity for woman to engage in, especially for a black one, and it expectedly earns Sula pariah status in the community of Medallion. The limitations of black female role are greater in a racist and exist society as is the amount of courage it takes to challenge them" (p.82).

In spite of their year of separation, and their opposite paths, Sula and Nel's relationship recollects its supremacy for each of them. Nel fells changed when Sula returns and this transformation is visualized in Nel's mind as she thinks of Sula's return as a cataract removed from her eyes; revealing her dull, boring, routine life:

It was like getting the use of an eye back, having a cataract removed. Here old friend had come home. Sula, who made her laugh, who made her see old things with new eyes, in whose presence she felt clever, gentle and little raunchy. (Sula, p.95)

Laughing with Sula in the old, familiar affectionate way, Nel feels "new, soft and new" (Ibid. p.98), the visual image indicates the women's intimacy throughout the novel. Sula ruptures this closeness between her and Nel by sleeping with Nel's husband, an act of little significance according to Sula' system of values, which Nel rejects. Sula feels sorrow because of Nel's attitude towards her; though sex is 'pleasant' and 'frequent' it is not as remarkable as her friendship with Nel. She has thought of Nel as her other self, but now she is separated from her and from unbounded freedom in life.

McDwell (1989) asserts that Sula's understanding the importance of her relationship to Nel results from selfunderstanding and intimacy, a process that Nel's marriage to Jude intrudes. "Like so many writers, Morrison equates marriage with the death of the female self and imagination" (p.82). Nel's sexuality is expressed not from her own pleasure, but rather, for the pleasure of her husband "and in obedience to system of moral judgment and moral virtue. It is impossible for her to imagine sex without Jude" (Sula, p.82). After she finds him naked with Sula, she regards her thighs - the metaphor for her sexuality - as "empty and dead ... and it was Sula who had taken the life from them ... the both of them ... left her with no thighs and no heart, just brain raveling away" (Ibid, p.110).

Sula intends no harm to Nel, believing her a "version of herself which she sought to reach out to and touch with an ungloved hand" (Ibid. p.121). The tactile image semiotically indicates how close and intimate Nel is to her, so she is surprised by Nel's rejection suddenly realizing that Nel has become "one of them," part of the town "and all its way" (Ibid. p 120). Sula offers no explanation for her behavior; she makes a distinction between sex and friendship - a view that Nel, attached to social conventions, does not share. As Sula explains later, she betrays her friend merely "to fill up an existential void" (Harding and Martin, 1994, p.103). Her relation with Jude is merely to fill space emptiness in her life, and to take revenge on the society which treats her like a pariah.

Jude' subsequent departure left Nel with "thighs [that] were really empty" (Sula, p.110). As Keith Byerman (1985) notes, "the loss of Jude is the loss of identity and the loss of life ... [Nel] now becomes a 'woman without a man' and is unable to raise her eyes. For this change she blames Sula, who without a sense of ownership, cannot conceive of Jude as 
an object to be taken" (p.198); Sula tell Nel: "What you mean take him away? I didn't kill him I just fucked him If we were such good friend, how come you couldn't get it over? "(Sula, p.145).

Sula gives expression to her own sexuality in a way "in which men have done ... for generations; she seeks to satisfy herself not others and is willing to have sex without committing herself emotionally to her partners, discarding them as she wishes"( Peach. Linden. "Chapter 3 Sula (1973)", Springer Nature, 1995).

Sula assumes the nature of the free black man, which is an aspect of Sula's freedom of sexuality to which Morrison herself has drawn attention in an interview:

Sula is a masculine character in that sense. She will do the kind of things normally only men do, that is why she is so strange. She really behaves like a man. She picks up a man, drops a man, the same way a man picks up a man, drop a man, the same way a man picks up a woman. And that's her thing. She's masculine in that sense. She's adventuresome, she trusts herself. She's not scared, she really ain't scared. And she is curious and will leave and try anything. (Harper and Stepto, 1979, p. 227).

Sula is sexually free, like her mother Hannah. But unlike her mother, she uses the men in the same way that they would use her. With Ajax, who loves the female power in Sula as he has loved it in his own mother, Sula assumes the upper position during their lovemaking which signifies her enjoyment of sex for its reflection of her own power.

With Ajax, Sula finds companionship with a man for the first time. During their lovemaking, she begins to imagine herself as an archaeologist digging through the layers of her lover's body in search of the mystery of his being. "After craving her way through the layers of black, gold and alabaster, she breaks through to loam. In that fertile medium she imagines herself mixing with him" (Harding and Martin, 1994, p.90): "I will water your soil, keep it rich and moist. But how much? How much water to keep the loam moist? And how much loam will I need to keep my water still? And when do the two make mud?" (Sula, p.131). With this new desire to join with Ajax and create something with him, comes the urge to bind him to her. The sexual images of moist fertile mud signify sexual fulfillment.

Sula begins to imitate the community values held by Nel. She cleans the untidy house, and for the first time stands before a mirror, "trying to decide whether she [is] good-looking or not" (Sula, p.13). This new-found concern with her reflected image "forebodes and adoption of the self-negating standards of femininity" (Harding and Martin, 1994, p.70) Sula tries to see herself as others see her, through the eyes of others, not of herself.

Ironically, Sula's new desire for stability, for nest, makes her lover think spontaneously of flight, "an urge derisively rendered literal by Morrison as Ajax tries to remember the date of the air show in Dayton" (Sula, p.71). This attraction to flight signifies his lack of commitment.

An earlier incident establishing Morrison's theme of the ambiguity of good and evil is Eva's crime of causing her son Plum's death. Eva's son Ralph (called Plum), returns from the First World War "shell-shocked and psychologically broken" (Samuels and Hudson-Weems, 1990, p.31). "Playing God" (Sula, p.31). Eva burns to death her drunken and broken son when she realizes that he wants to crawl back into her womb rather than to function like a man (www.viterbo.edu). For Morrison, the relationship with the mother is always ambiguous, "revelatory yet destructive, even for women" (Rigney, 1991, p.14); but the male desire to return to womb, to reenter the mother, is more often related negatively with a submission of consciousness or a death wish. Eva justifies her burning to death of Plum to her daughter Hannah:

I ain't got the room no more even if he could do it. There wasn't space for him in my womb. And he was crawling back. ... I had room enough in my heart, but not in my womb. ... I birthed him once ... God have mercy, I couldn't birth him twice ... So, I just thought of a way he could die like a man not all crunched up inside my womb, but like a man ... a big man can't be a baby all wrapped up inside his mamma no more; he suffocates ... But I held him close first. Real close. Sweet Plum. My baby boy (Sula, pp.71-72)

Plum's death visualizes Eva's power as what Barbara Christian calls "primeval Earth Mother Goddess: she both gives life and takes it away. She performs a ritual killing inspired by love - a ritual of sacrifice by fire" (www.viterbo.edu). Yet, Eva "pays the price for her violent love" (Otten, 1989, p.32) when she cannot save the innocent Hannah from death by fire.

Hannah is burnt while tending a fire in the back yard. Eva tries desperately to save her first-born child, while Sula stands watching without fear; Sula recalls the scene on her deathbed to Nel. The disturbing distance she feels from her mother is clear when she offers no help at all - "I stood there watching her burn and was thrilled. I wanted her to keep on jerking like that, to keep on dancing" (Sula, p.147).

Sula, like the Peace woman in her family, is left alone. On her deathbed, she is visited by Nel, but their painful meeting does not bring reconciliation. Moreover, Sula questions Nel's belief of what is right and what is wrong according to her understanding and to the norms of the society, which indicates Nel's clinging "to her lost innocence by repressing the side of herself that Sula mirrors like the prototypal serpent in Eden" (Otten, 1989, p.42). Sula attempts to question Nel's certainty in their last conversation, with significant references to the ambiguity of good and evil:

She opened the door and heard Sula's slow whisper. 
"Hey girl." Nel paused and turned her head but not enough to see her

"How you know?" Sula asked.

"Know what?" Nel still wouldn't look at her.

"About who was good. How do you know it was you?"

"What mean maybe it wasn't you. Maybe it was me." (Sula, p.146)

Sula thinks as Nel leaves her: "So, she will walk on down that road, her back so straight in that old green coat ... thinking how much I have cost her and never remember the days when we were two throats and one eye and had no price" (Ibid. p.147).

It is a very evocative image for what women can be to each other, "the pricelessness they achieve in refusing to sell themselves for male consent, the total worth they can only find in each other's eyes" (Smith, 1979, p.191). Though the two of them might share a common vision suggested by "one eye", their needs and desires are different; evidenced by their "two throats".

Even in her death, Sula is unable to be free of Nel. She dies alone, but her dying comment - "wait'll tell Nel" (Sula, p.49) -is seen an appeal to the other half of her equation. Twenty-five years later, Nel, at Sula's grave, respond to the appeal directed to her soul by her lost friend:

"Sula?" she whispered, gazing at the tops of trees "Sula?" All the time,

all the time, on her chest and came up into her boat. "We was girls

together," she said as though explaining something. "O Lord, Sula"

she cried. "girl, girl girl, girl". (Ibid. p.174)

Nel mourns her lost friend, mourn the loss of self; the process of mourning and remembering leads to intimacy with the self which consequently leads to making intimacy with others possible. Perhaps Nel's cry, in the last line of the novel, "a primal scream beyond and above the language, is a reinstatement of the semiotic from which her own mother has separated her as well as herself" (Rigney, 1991, p.104): "It was a fine cry - loud and long - but it has no bottom and it had no top, just circles and circles of sorrow" (Sula, p.147). The cry is described as beyond and above language, reflecting the extreme pain Nel has been suffering from that no language can express. It is also an indication of the separation of herself from the other self 'Sula' by her mother and the society's norms and the traditions which she submits herself to.

\section{CONCLUSION}

Sula's personality is shaped through her environmental circumstances which form her rebellious, independent character. Her grandmother Eva Peace loses her legs purposely in the railroad track to collect the insurance money and support her family which indicates her will to survive.

Sula fights against the prescribed roles for black women, insisting that she wants to be herself, distinct from others.

Sula's capacity to begin violence is evidenced when she protects herself and Nel from a group of abusive white boys by slicing the top of her finger, a sign of warning to them of how dangerous she is.

Her ability to begin violence is also evidenced when she accidently drowns Chicken Little. She swings him vigorously and lets slip from her hands into the nearby river.

Sula and Nel complement each other; Sula animates Nel's will to power, while she finds in Nel the opposite of her own nature. One is meek while the other is fierce. Their closeness to each other is described by the narrator as if they are one eye and two throats.

When Sula returns to Medallion years later, she does not accept the domestic prescribed role of the black women. She expresses her free will sexually, using men for her own pleasure, and discarding them. While lovemaking, she assumes the upper position as a sign of her control.

She, unwittingly, severs her friendship with Nel by one sleeping with her husband. In her opinion, Jude simply fills in a space in her empty life, and it is her way to take revenge on the society which treats her as a pariah.

With Ajax, Sula tries to fit in with in with the community values by cleaning the untidy house, and even taking care the way she looks, because with him she finds companionship with a man in the first time in her life. But Ajax proves to lack commitment.

Twenty five years after Sula's death, Nel comes to realize that she has blamed Sula for her own failure in life, and has missed her all the time. Her loud cry at the end of the novel utters the extreme pain of the loss that no language can express.

\section{REFERENCES}

[1] Banyiwa-Horne, N. (1985). "The Scary face of the Self.". Analysis of the Character of Sula in Toni Morrison"s Sula. Sage: A Scholarly Journal of Black Women, 2 (1), 28-31.

[2] Busia, Abena. P.B. (1988). Black Feminist Criticism and Critical Theory. Eds. Weixmann Joe \& Baker Hurston, Jr. Florida: The Penkeville Publishing.

[3] Byerman, K.E. (1985). Beyond Realism: The Fictions of Toni Morrison" Fingering the Jagged Grain: Tradition and Form in Recent Black Fiction. U Georgia, 184-216.

[4] Christian, B. (1980). Black women Novelists: The Development of a Tradition 1892-1976. Westport, CT: London: Greenwood 
Press.

[5] Grant, R. (1988). “Absence into Present: The Thematic of Memory and "Missing" Subjects in Toni Morrison's Sula." Critical Essays on Toni Morrison. Ed. Nellie Y. McKay. Boston, Massachusetts. G. K. Hall \& Co. pp. 90-103.

[6] Harding, W. \& Martin, J. (1994). A World of Difference: An Inter Cultural Study of Toni Morrison's Novels. Westport, CT: Greenwood.

[7] Harper, M.S. \& Stepto, R.B. (1979). Chant of Saints: A Gathering of Afro-American Literature, Art, and Scholarship. Urbana: University of Illinois Press.

[8] McDowell, D.E. (1988). The Self and the other': Reading Toni Morrison's Sula and the Black Female Text. Critical Essays on Toni Morrison. Ed. Nellie Y. McKay. Boston: G. K. Hall \& Co.

[9] McKay, N.Y. (1988). Critical essays on Toni Morrison. Boston, Mass: G.K. Hall.

[10] Morrison, T. (1973). Sula. New York: Alfred. A. Knopf, Inc. U.S.A.

[11] Morrison, T. (1984). "Rootedness: The Ancestors as Foundation." Black Women Writers (1950-1980). Ed. Mary Evans. New York: Anchor Press Doubleday.

[12] Morrison, T. (1985). Talk at A.F.E.A. Conference on American Women Writers, University of Toulouse. In.

[13] Otten, T. (1989). The Crime of Innocence in the Fiction of Toni Morrison. Columbia: University of Missouri.

[14] Parker, B. (1979). Complexity: Toni Morrison's Women an Interview Essay. Sturdy Black Bridges: Vision of Black Women in Literature. Ed. Roseann P. Bell, Betty J. Parker, and Beverly Guy-Sheftall. New York: Anchor Press.

[15] Peach L. (1995). "Chapter 3 Sula (1973)". Modern Novelists Toni Morrison. Macmillan Publishers Limited, Palgrave, London.

[16] Rigney, B.H. (1991). The Voices of Toni Morrison. Colombian: Ohio University Press.

[17] Russell, S. (1991). Render Me My Song: African-American Women Writers from Slavery to the Present. New York: St. Martin's Press.

[18] Samuels, W.D. \& Hudson-Weems, C. (1990). Toni Morrison. Boston: Twayne Publishers.

[19] Smith B. (1979). Toward a black feminist criticism. Women's Studies International Quarterly 2(2): 183-194.

[20] Stepto, R. (1979). "Intimate Things in Place: A Conversation with Toni Morrison", Chants of Saints (Urbana: University of Illinois Press,), 215-17.

[21] Tate, C. (1989). ed. Black women writers at Work. New York: Continuum.

[22] Washington, M.H. (1990). ed. Midnight Birds: Stories by Contemporary Black Women Writers. Anchor Books. Bantam Publishing Group, Inc. U.S.A.

[23] Willis, S. (1982). Eruptions of Funk: Historicizing Toni Morrison. Black American Literature Forum, 16(1), 34-42.

[24] Wisker, G. (2000). Post-Colonial and African American Women's Writing “Chapter 3 Toni Morrison”. N.Y.: St Martin's Press.

[25] Young, M.E. (1993). Mules \& Dragons. Westport C.T. Greenwood Press.

[26] africandiasporaphd.com (accessed 3/8/2018)

[27] baadalsg.inflibnet.ac.in (accessed 3/8/2018)

[28] othes.univie.ac.at (accessed 4/8/2018)

[29] repositorio.ual.es (accessed 4/8/2018)

[30] shodhganga.inflibnet.ac.in (accessed 5/8/2018)

[31] www.viterbo.edu (accessed 5/8/2018)

Afaf A. Al-Saidi is Associate Professor in British-American Literature at Aden University, Republic of Yemen. She finished her Master Degree at Aden University in 1994 and her PhD from College of Arts, Cairo University in 2000. She has extensive experience teaching literature courses in Aden University Dr. Al-Saidi realized her interest in literature when she was a student at Aden University and developed this interest in her higher education (Master and $\mathrm{PhD}$.). She has contributed in several literature conferences inside and outside Yemen.

Shunayfaa M. Alqarni, the corresponding author, received a PhD degree in Literature from King Khalid University in 2007. She has been teaching since 1990 and is currently Associate Professor in British-American Literature of the College of Languages and Translation at King Khalid University. Her research interests fall broadly within the field of literature. Dr. Alqarni has published several articles in reputable journals. Her most recent research projects are on Journal of Oriental Studies (SOLGEU) - Issue no. 58, pp. 5-28, January 2017, Journal of Language Teaching and Research, Vol. 6, no.6, pp. 1225-1231, November 2015 and Journal of the Faculty of Education, Mansoura University, Egypt - Issue 90, January 2015 respectively. 